\title{
The Academic Librarian and Information Technology: Ethical Issues
}

\section{Lawson Crowe and Susan H. Anthes}

\begin{abstract}
Academic librarians face a new working environment engendered by the rapid growth of information and advances in information technology. New conditions create ethical considerations that go beyond questions of individual behavior. Value conflicts and ethical dilemmas arise from the more active, substantive role required of the academic librarian by technological developments. The librarian's commitment to freedom of access to information is challenged by issues such as fee-based information service and governmental restrictions on information access. Academic librarians must be sensitive to ethical requirements inherent in their role as information mediators.
\end{abstract}

merican librarians have been concerned with the ethical aspects of their profession since at least the middle of the nineteenth century. ${ }^{1}$ For the most part, the earliest of these discussions emphasized the responsibilities of the librarian to employer and patrons and raised the issue of the librarian's deportment, frequently offering hortatory instruction as to appropriate dress and demeanor. Ethics and etiquette not being sharply distinguished, these treatises were the equivalent of instructions to physicians on their "bedside manners." ${ }^{2}$

The library was perceived as a repository of books and documents. The academic library in particular was understood to be the place where recorded knowledge was collected and where the "transcript" of the culture was preserved for transmission to future generations. ${ }^{3}$ Within this framework of values, the academic librarian was concerned primarily with the technical requirements of collection building and maintenance, with books, serials, and documents, and only secondarily directed toward users who, in turn, tended to regard librarians as caretakers of the collection. ${ }^{4}$

This early perspective on the academic library and the academic librarian changed drastically after World War II. The new Code of Ethics adopted in 1981 by the American Library Association reflects this expansion. Its emphasis on freedom of access to information, resistance to censorship, protection of the user's right to privacy, and quality of service speaks to the new and radically altered environment in which academic librarians now find themselves. ${ }^{5}$ Commentators have noted the dual impact of the growth of information and the rise of technology for its management. Indeed, the issue is not merely growth and new technology. Rather, it is the accelerating rate of growth and the accelerating rate of change in information technology that have created the new environment. In this environment, there is a critical need for ethical reflection and sensitivity regarding the li-

Lawson Crowe is Professor, Department of Philosophy, and Susan H. Anthes is Assistant Science Librarian at the University of Colorado, Boulder, Colorado 80309. 
brarian's professional duties and his or her place within the context of the institution served. ${ }^{6}$

The twentieth-century inventory of information is increasing exponentially, requiring significant changes in academic libraries and in the work of academic librarians. These changes have not been explicitly and universally recognized by librarians, administrators, and legislators, and are only beginning to be perceived by some library users. It is, however, abundantly clear that no individual library can acquire all of the information demanded. The "feverish collection building" of the immediate post-World War II decades has given way to selectivity in collection development. ${ }^{7}$ The multitude of information sources, not all of which are of equal value, has brought virtually all academic libraries squarely up against the limitations of finite budgets, space, and staff. Whereas the library was once thought of as a collection of books, it now appears that the central purpose of the contemporary academic library must be to provide its users with access to information. ${ }^{8}$

\section{"... the quality and nature of ser- vices provided for information access are at least as significant as the size of a particular collection."}

This conceptual expansion of the library's objective has serious implications for academic librarians. First of all, the quality and nature of services provided for information access are at least as significant as the size of a particular collection. Secondly, attention is diverted from traditional information containers, e.g., books and journals, to formats made possible by the new technology. The librarian's task now includes not only providing access to the library's own collection, but also achieving fast, reliable access in convenient, readable form to information residing in other, perhaps distant, collections. Academic librarians must manage access to the growing body of knowledge and maximize its usefulness for stydents and researchers.

The new technology, like other innovations, was feared initially because it could be put to questionable uses. For example, there was concern that the new technology might be employed to compromise user privacy.' Some also thought that it might depersonalize the learning process or encourage students to confuse mere accumulation of information with genuine education. In retrospect, it seems fair to say that this latter fear was unfounded.

Advances in information technology have brought about increased efficiency in the acquisition, preservation, and management of library collections. Card catalogs are closing in favor of their online counterparts. Many of the bibliographic and processing procedures of the past are now automated. But most significantly, information technology has created an entirely new working environment. ${ }^{10}$ First, we now have the capacity to make fundamental changes in student instruction, thereby enhancing the learning experience. In the course of approaching a specific subject, students can learn to use new electronic-based bibliographic techniques with broad potential applications. Indeed, failure to awaken both students and faculty to this possibility may lead to a generation of educationally disadvantaged students.

Secondly, the emergence of electronic technology clearly serves the primary information access requirements of the academic library. The academic community's needs have intensified demands on the academic librarian as information access mediator. Without much recognition from administrators and with little or no additional staff support, many academic librarians have had to become information specialists who are not simply links but active participants in the chain of communication. Hence, the librarian now needs to understand better the terms and concepts that are critical to discovering the information sought. The extent of such knowledge of subject fields will, in many cases, determine whether demands for information can be met. The academic librarian is, perhaps as never before, in a position to 
offer significant help or significant harm to library users. ${ }^{11}$

\section{PROFESSIONAL COMMITMENTS AND THEIR ETHICAL IMPLICATIONS}

The academic librarian's mission entails adherence to certain principles that have ethical implications. While an emphasis on job preparation has infected higher education generally, those institutions stressing liberal learning hold as their major mission the development of the capacity for critical thinking and questioning in their students. American colleges and universities are founded on the belief that the expansion of understanding and the development of individual autonomy are absolutely necessary for a free and democratic society. Although the academic librarian has long played an essential part in this process, the potential for contributing to all levels of instruction has been greatly expanded by the new environment. Teaching research strategies, information acquisition skills, and directly supporting the user's search for information are rapidly growing aspects of the academic librarian's work.

\section{"The professional and ethical duty of the academic librarian is to promote the reasoned inquiry that 'ennobles a human life and contributes to human excellence.' "'}

Participation by librarians in the central mission of the university requires a commitment to the principle of free access to information, to reasoned inquiry, and to the value of public discourse and scrutiny of contending opinions. Unqualified support for research, the advancement of knowledge, and free expression of the results of such study are also implied. The academic librarian must necessarily reject and resist any attempt to censor library materials on the grounds of personal taste or prejudice.

Adherence to these principles is an ethi- cal act that has both philosophical and political meaning. It assumes that absolute certainty on most significant societal questions probably cannot be achieved and that truth will be revealed only in open and unfettered discourse, not imposed by dogma or doctrine. Freedom of access to information and impartiality in the administration of that access are fundamental aspects of human freedom and necessary conditions for the fulfillment of human dignity. They promote objectivity and respect for others and are essential for the formulation and expression of informed opinion. The professional and ethical duty of the academic librarian is to promote the reasoned inquiry that "ennobles a human life and contributes to human excellence." ${ }^{12}$

Unfortunately, a belief in free access and free expression, or what Archibald MacLeish called freedom of the mind, is not shared by all. The guarantees of the First Amendment notwithstanding, some people have argued for suppression of a variety of materials on grounds such as community standards and tastes, religious beliefs, and national security. The professional commitment of the academic librarian, however, is inconsistent with such practices. Every library contains books filled with erroneous opinions, outdated information, sophistry, propaganda, and pure silliness. The task is not to prevent the user's encounter with such materials. Rather, the purpose of the librarian is to enlarge the power of inquiry, to stimulate imaginative questioning of conventional thinking and burdensome customs, and to enhance analytic skills in students and their teachers by providing access to a meaningful range of materials dealing with the world and the human condition.

\section{THE NEW ENVIRONMENT GENERATES ETHICAL PROBLEMS}

Virtually every issue of current interest to librarians has been made complex by the new environment described above. Librarians' professional status has been debated for many years, but demands for new and sophisticated services have made 
its reconsideration urgent. Problems associated with information literacy, the automation of various library functions, possible invasions of user privacy, attempts by federal agencies to restrict access to public documents, and commercialization of information are affected by the expansion of information and the technology for its management. Reduced funding and limited physical space in libraries are also features of the information age.

The academic librarian as information mediator must acquire deeper and broader subject expertise, adapt to the built-in obsolescence of available technology, and prepare for new information storage and retrieval capabilities. In respect to both technique and substantive content, the mediator must be more directive in relationship to the user. The modern academic librarian must be clientoriented rather than medium-oriented. At the same time, he or she must recognize the needs of the institution and society generally. In offering bibliographic services, and by discriminating among materials acquired, the academic librarian may stand in the midst of contending interests. It is at this confluence of values that ethical conflicts arise.

\section{"Unquestioned conformity to rules and regulations is neither a necessary nor sufficient condition to make an action ethical."'}

There are at least four loci of values to consider. First, there are broadly held societal values such as entitlement to life, liberty, and the pursuit of happiness; equal justice before the law; equal opportunity; freedom of expression; the rights to property and due process; and others guaranteed by the Constitution of the United States: national security, respect for persons, and domestic tranquility. These and similar values form the common moral framework for our society. Second, there are the aforementioned values of professional librarianship in association with the values of the academy. Third, academic librarians hold personal values. The force of personal values will be affected to the degree to which the professional values of librarianship have been internalized. Fourth, the values of individual library users will affect their expectations and the relationship they have with librarians.

\section{PROFESSIONAL AND SOCIETAL ETHICAL PROBLEMS}

Ethical issues specific to academic librarianship arise in the ordinary course of professional duties when any or all of the values described above conflict. The academic librarian may be tempted to substitute personal values for professional values. For example, impartiality in the administration of access to information may be compromised when information is requested by someone for whom access to the material is judged to be unsuitable. Or the librarian may be faced with a demand by persons outside the library to suppress or remove materials because they are viewed as offensive. Or the librarian's professional values may conflict with societal values when, for example, in the role of information specialist, he or she is invited to aid what appears to be illegal or immoral activity, e.g., when information about bomb-building or toxic substances is requested. Or again, societal values may create ethical conflicts when a legitimate authority demands that the librarian violate a user's privacy, or when an authority demands that library materials containing sensitive information be surrendered and thus made unavailable to users.

These examples illustrate a characteristic feature of value conflict. The conflict is not always between two persons or two groups adhering to different values. Often the conflict is within one person whose professional values may conflict with personal convictions or with societal values. In other words, ethical issues present dilemmas in which at least two mutually exclusive courses of action seem to be required. This is one reason why ethical admonitions sometimes sound like pious platitudes to those who face real problems in the real world. 
The academic librarian should not withhold information and ought to respect the user's right to privacy. But what should the librarian do when asked to provide information on bomb-building or, for that matter, to provide assistance in gaining any information when there is strong reason to believe that the purposes of the user are illegal and immoral? As Robert Hauptman points out in his brief but celebrated paper on this subject, it has been traditional in the ethics of librarianship to insist that the librarian be essentially neutral and self-effacing in service to the user. ${ }^{13}$ In particular, personal beliefs are to be subordinated to the needs of the patron. Hauptman's experiment consisted of requesting bomb-building information from a number of reference librarians, none of whom declined to help him on ethical grounds. He suggests that the reference librarians did not distinguish between their professional responsibility as disseminators of information and their duties to society, although the two were clearly in conflict. It is worth noting that Hauptman's experimental subjects were not informed that they were in fact subjects, an ethically unacceptable condition for human research. Nevertheless, the question remains: are academic librarians responsible to society in the situation Hauptman created?

Truly, it is an ethical dilemma. Every member of society has a moral and legal obligation to prevent crime and not to aid wrongdoing. The librarian has the same duty, but also has a professional responsibility to disseminate information and to respect the user's privacy. As a general rule, the librarian's disposition toward the user's intent is expected to be nonjudgmental; but in this situation, if the librarian fulfills one duty, he or she will abjure the other. How can such a dilemma be resolved?

The choice of one duty over others may be painful and leave a residue of dissatisfaction. There are times, however, when painful choices must be made, and in most instances, we opt for what we believe represents a higher value. A passionate commitment to impartiality in the administration of access to information and a belief in the freedom of the mind do not require the abandonment of all other values. There is ample precedent for recognizing societal responsibility. Physicians, for example, are required by statute to violate patient confidentiality in order to report various contagious diseases, child abuse, and gunshot wounds. The need of society to be secure from terrorist and other criminal action has a legitimate ethical claim on every citizen, including academic librarians. In short, the ethical and professional requirement to promote freedom of access to information and to respect the user's privacy may be subordinated in an attempt to prevent crime and maintain civil order. One would hope that an academic librarian in the situation Hauptman created would resolve the dilemma in favor of societal responsibility.

But what about the reference librarians who did not object on ethical grounds to assisting Hauptman? Does his experiment show that they were unethical? Probably not. It suggests that they acted in a conventional manner consistent with their usual practice and, perhaps most significantly, that they did not recognize the ethical test to which Hauptman put them. This illustrates why ethics are not simply rules to be learned once and for all. We are inclined to believe that what is done by virtue of habit, custom, or professional training is the right thing, ethically and otherwise. What makes an action right, however, is more than these things and more than intuition or feelings.

At a minimum, an ethical action must take into account the common moral framework of values, and it must be based on a rational assessment of particular circumstances. Unquestioned conformity to rules and regulations is neither a necessary nor sufficient condition to make an action ethical. We must ask why we accept the rules we do, what interests they serve, and what values they protect. In short, only when we make our values explicit are we in a position to make ethical choices. Information provides access to knowledge which in turn shapes and directs the behavior of others. ${ }^{14}$ The contemporary academic librarian's capacity for providing accurate and precise information makes ethical sensitivity to value conflict an es- 
sential part of the librarian's work.

Societal ethical problems generated by the advance of information technology go beyond the relationship of the academic librarian to the individual user. The problem is one of information policy for the entire society. Academic librarians, and indeed all professional librarians, must assess the new role of the library in the "information society." There is an urgent need to achieve for the institution " a higher place on the societal agenda. ${ }^{\prime 15}$ Indeed, several recent, ominous trends argue for active political engagement by librarians.

The federal government's policies for gathering and disseminating information and concerning possible misuse of information technology itself represent two such trends. The number of published government documents has been significantly reduced. The Office of Management and Budget is setting other information access policies. Government Printing Office bookstores have been closed, and the monthly Selected U.S. Government Publications list has been cancelled. While libraries within the depository system may still receive one copy of each depository item, the number of items is being reduced and no provisions currently exist for free access to documents in electronic form. ${ }^{16}$

Our national information policy must be based on the principles and values of our society. Freedom of expression as protected by the First Amendment and due process of law as protected by the Fourteenth Amendment are meaningless in the absence of access to information. Where information about the workings of government can be denied or withheld, development and execution of policy is left solely in the hands of bureaucrats and interest groups hoping to influence them. Recent federal scandals reveal how undesirable this can be.

The present federal administration sells information to private companies for resale at a profit. Access to this information is limited to those who can pay for it. In a sobering article, Anita Schiller and Herbert Schiller describe in detail the transfer of the national stock of information from government custodianship to private ownership and control. ${ }^{17}$ This packaging and transmission of information for profit represents a departure from a national commitment to an informed citizenry. Private information vendors argue that whatever can be done privately for profit should not be done by government, but this principle ignores the fact that the information already belongs to the people to whom vendors expect to sell it. While private industry claims that rendering the information usable justifies a fee, the fact remains that the federal government could

\section{"The shift of information control from the public sector to the private sector is continuing at a rapid pace. ..."}

do the same thing and guarantee equitable access.

The Information Industry Association, a trade group representing 150 companies, has lobbied to dismantle the National Technical Information Service, advocated higher user fees for the information services of the National Library of Medicine, and brought similar pressure to bear on other agencies. The shift of information control from the public sector to the private sector is continuing at a rapid pace, but so far no one has determined how free access to government-produced information, regardless of its format, will be maintained. This must become a central issue for academic librarians and their patrons.

The privatization of government information and the development of electronic databases generally have produced another ethical issue for the information society in the form of the fees now charged for database searching. It is clear that information technology has profound budgetary implications for academic library staff, capital equipment, and space. Fees to the so-called end-user have seemed to many administrators the only option for covering, at least in part, the cost of the 
growing demand for this service. Such fees applied within colleges and universities, however, are inherently discriminatory. They serve to divide the information rich from the information poor. Because our principle ought to be equality of access to information and impartiality in the administration of that access, fees can be expected to thwart a basic objective of the academic library. As of this moment, it appears that the budgetary, administrative, and ethical problems surrounding fee policy have not been addressed in most institutions.

Finally, the Information Industry Association and the American Library Association have been able to make common cause, with apparent success, in opposing the latest federal effort to restrict access to unclassified government information. Admiral Poindexter, former National Security Advisor to President Reagan, announced a National Security Decision Directive in November 1986 to the effect that the head of each federal agency had the right to assign a new security classification, "Sensitive but Unclassified" to any information "the disclosure, loss, misuse, alteration or destruction of which could adversely affect national security or other federal government interests." 18 In addition, the Department of Defense recommended the establishment of a monitoring system to detect any "unusual" use of the several federal and private databases that hold unclassified, technical information.

The ostensible purpose of this directive was to prevent foreign governments from gaining access to unclassified, technical information, but the effect of the directive would have been far more sweeping. The new category also included "economic, human, financial, industrial, agricultural, technological, and law enforcement information." Testimony at congressional hearings revealed that files on hazardous material transportation, flight safety, Securities and Exchange Commission records, Social Security Administration records, and Federal Reserve monetary policy might also be included. In short, a government official, accountable only to the president, could deny public access to almost any government information. It was also reported that CIA and FBI agents have already begun visits to private information companies to inquire about who used their services. It appears so far that lobbying efforts against the implementation of the directive have succeeded; but obviously the threat remains. ${ }^{19}$

These three issues-privatization of public information, fees for service to database users, and attempts to restrict information by government agenciespresent ethical problems as well as political, technical, and administrative ones. That they are ethical issues is revealed in two ways: (1) as policies they have a direct and deleterious impact on the central mission of the modern academic library, and (2) as political, technological, and administrative matters they represent how things are to be done, but not whether they should be done. How things are done is a purely technical matter, but which things are done and why, among all the possible alternatives, are ethical questions. It is directly related to what we understand our ethical duties to be and the ultimate social consequences of carrying out what has been proposed. This has special significance for academic librarians beset as they are by the impact of information technology.

\section{CONCLUSION}

One way to judge the ethical significance of an action is to consider its consequences. In the case of librarianship, the consequences of an action or a policy must be viewed in light of both professional commitments and responsibility to society. A democratic society's fundamental belief in freedom of expression implies freedom of access to information. Therefore, it is the ethical duty of the academic librarian to guarantee that access and to resist any policy or practice that limits or denies free access. ${ }^{20}$

It is ironic that the extraordinary development of information technology, which has made the academic librarian more effective, more efficient, and able to make new contributions to instruction, also has 
the potential for misuse and frustration of the librarian's objectives. Only a heightened ethical awareness and sensitivity on

the part of the academic librarian can promote the former and prevent the latter.

\section{REFERENCES AND NOTES}

1. Guy A. Marco, "Old Wine in New Bottles," Ohio Library Association Bulletin 36:8-14 (Oct. 1966), as reprinted in American Library Philosophy: An Anthology, ed. Barbara McCrimmon (Hamden, Conn.: Shoe String, 1975), p.193.

2. Jonathan A. Lindsey and Ann E. Prentice, Professional Ethics and Librarians (Phoenix, Ariz.: Oryx Pr., 1985), p.1-3.

3. Jesse H. Sherra, "What is Librarianship?" Louisiana Library Association Bulletin 24:95-97, 117-18 (Fall 1961), as reprinted in American Library Philosophy, 1975.

4. Mary Lee Bundy and Paul Wasserman, "Professionalism Reconsidered," College and Research Libraries 47:5-26 (Jan. 1986).

5. Lindsey and Prentice, Professional Ethics and Librarians, p.7; Kennth G. Peterson, "Ethics in Academic Librarianship: The Need for Values," Journal of Academic Librarianship 9:132-37 (Mar. 1983).

6. Nethery Wylie, "Mega Gaps: The Exclusion of Libraries from Public Discussion of the Information Age," Colorado Libraries 13:20-21 (Mar. 1987); Margaret F. Steig, "Fee vs. Free in Historical Perspective," Reference Librarian 12:93-103 (Feb. 1985); Sherra, "What is Librarianship?" p.117; Eli M. Oboler, To Free The Mind: Libraries, Technology, and Intellectual Freedom (Littleton, Colo.: Libraries Unlimited, 1983), p.27.

7. Bundy and Wasserman, "Professionalism Reconsidered," p.9.

8. Gordon R. Williams, "The Function and Methods of Libraries in the Diffusion of Knowledge," in The Role of Libraries in the Growth of Knowledge, ed. Don R. Swanson (Chicago: Univ. of Chicago Pr., 1980), p.58-75.

9. Jesse H. Sherra, "The Compleat Librarian": and Other Essays (Cleveland, Ohio: Case Western Reserve Univ. Pr., 1971), p.175.

10. Sherra, "What is Librarianship?"

11. Lindsey and Prentice, Professional Ethics and Librarians, 1985.

12. Elias Baumgarten, "Ethics in the Academic Profession," Journal of Higher Education 53:282-95 (1982). We are indebted to Baumgarten's excellent discussion which, while primarily about teaching faculty, also applies to academic librarians.

13. Robert Hauptman, "Professionalism or Culpability? An Experiment in Ethics," Wilson Library Bulletin 50:626-27 (Apr. 1976).

14. Nethery Wylie, "Mega Gaps."

15. Carolyn M. Gray, "Information Technocracy: Prologue to a Farce or a Tragedy," Information Technology and Libraries 6:3-9 (Mar. 1987).

16. Ibid.

17. Anita R. Schiller and Herbert I. Schiller, "Who Can Own What America Knows?" The Nation (Apr. 17, 1982), p.461-63.

18. "Federal Government Cracking Down on Public Information Files," Database End-User 2:33 (Dec. 1986); see also, "IIA Opposes Restrictions on Unclassified Databases," Information Today 4:1 (Jan. 1987).

19. "'Poindexter Memorandum' Dumped After Forum," American Libraries 18:238 (Apr. 1987).

20. American Library Association, Commission on Freedom and Equality of Access to Information, Freedom and Equality of Access to Information (Chicago: ALA, 1986). 